УДК 621.314

\title{
V. YASKIV
}

\section{EXPERIMENTAL RESEARCH OF HIGH-FREQUENCY MAGAMP POWER CONVERTERS FOR SYNCHRONOUS RECTIFICATION}

\author{
Ternopil Ivan Puluy National Technical University \\ 56 Ruska str., Ternopil, Ukraine.E-mail: yaskiv@yahoo.com
}

\begin{abstract}
The results of experimental research of high-efficiency high-frequency power supplies for specialized computer systems that require high load current at low output voltage are given in the article. In particular, the new methods for the design of MOSFET synchronous rectifiers in power converters based on high-frequency magnetic amplifiers are investigated. The proposed methods allow obtaining significantly higher power converters efficiency compared to existing ones.

Keywords: power converter, MOSFET synchronous rectifier, high-frequency magnetic amplifier, high efficiency

Анотація У статті наведені результати експериментальних досліджень високоефективних високочастотних джерел живлення для спеціалізованих комп'ютерних систем, які потребують високого струму навантаження при низькій вихідній напрузі. Зокрема, досліджуються нові методи проектування синхронних випрямлячів MOSFET в перетворювачах потужності на основі високочастотних магнітних підсилювачів. Запропоновані способи дозволяють отримати значно більшу ефективність перетворювачів потужності порівняно з існуючими.

Ключові слова: перетворювач потужності, синхронний випрямляч MOSFET, високочастотний магнітний підсилювач, висока ефективність

DOI: 10.31649/1681-7893-2019-38-2-113-121
\end{abstract}

\section{INTRODUCTION}

Modern specialized computer systems often require high-frequency power supplies with high level of the load current at low level of the output voltage. This current may be equal to several dozens or, sometimes, hundreds of amps. The decisive characteristic of such a converter is its efficiency. It is known that the main losses in modern high-frequency power converters are the losses on the diodes of the output high-frequency rectifier. At a high level of the load current, they are particularly noticeable and significantly reduce not only the efficiency of the power converter, but also worsen its specific power, the level of reliability, the level of electromagnetic interference, quality of the output voltages, its dynamic characteristics.

The so-called Schottky diodes, which can be used as rectifying diodes of the output high-frequency rectifier, somewhat reduce its losses level due to smaller value of the direct voltage drop. However, this solution cannot be satisfactory at high load current levels.

In addition, high-frequency power converters with high level of the load current must satisfy the following requirements [1]: $100 \%$ range of the change of the load current; high quality of the output voltages; low level of the electromagnetic interferences; high level of the specific power; must allow a wide range of input voltage change; high reliability; low cost.

With the appearance of high-frequency MOSFETs there has developed a new rectifier topology: synchronous rectifier. Its novelty consists in the use of a MOSFET instead of a rectifying diode, which is controlled in a function of voltage of high-frequency power transformer secondary winding (synchronously with this voltage) [2-4]. The use of MOSFET synchronous rectifiers in push-pull circuits leads to short-circuit currents. Therefore, the use of MOSFET synchronous rectifiers in push-pull circuits requires a solution to this problem. For this purpose, respectable control circuits and specialized drivers are being developed. Works [5-7] describe digital solutions for synchronous rectifier control. They significantly complicate the circuitry of the converters. Works $[1,8]$ propose methods for using synchronous rectifiers in power converters based on high frequency magnetic amplifiers that do not require specialized control circuits. This article is dedicated to the experimental study of such power converters.

\section{FUNDAMENTALS OF MAGAMP POWER CONVERTER DESIGN}

A MagAmp, used as a switch, can block and delay the applied voltage. However, MagAmp cannot interrupt the current once started. Hence, MagAmps are used in pulse circuits where they are assisted by diode rectifiers, which cut off the current.

(C) V. YASKIV, 2019 
MagAmp is just a coil wound on a core of amorphous alloy with a relatively rectangular hysteresis loop (fig. 1) [1, 8-12].

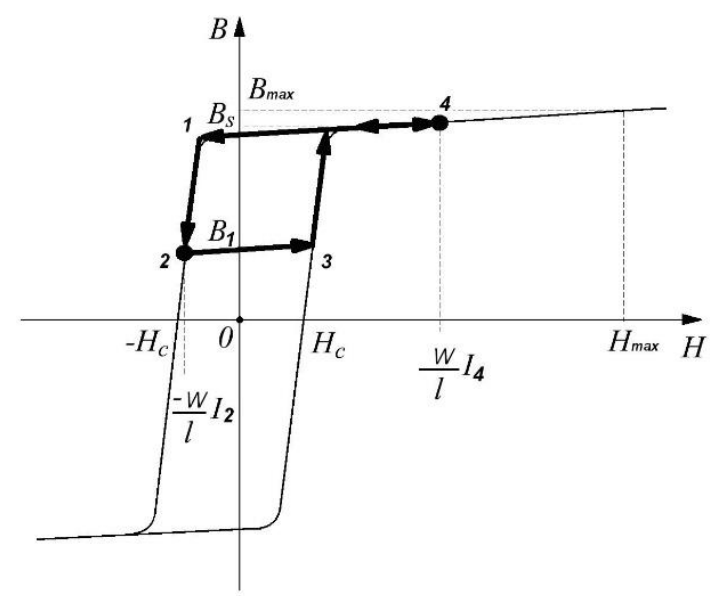

Fig. 1. Hysteresis loop of MagAmp core material [1]

When the voltage of negative polarity is applied to MagAmp, its core demagnetizes (corresponds to 1-2 slope in fig. $1 ; \mathrm{t}_{1} \ldots \mathrm{t}_{2}$ in fig. 2 ).

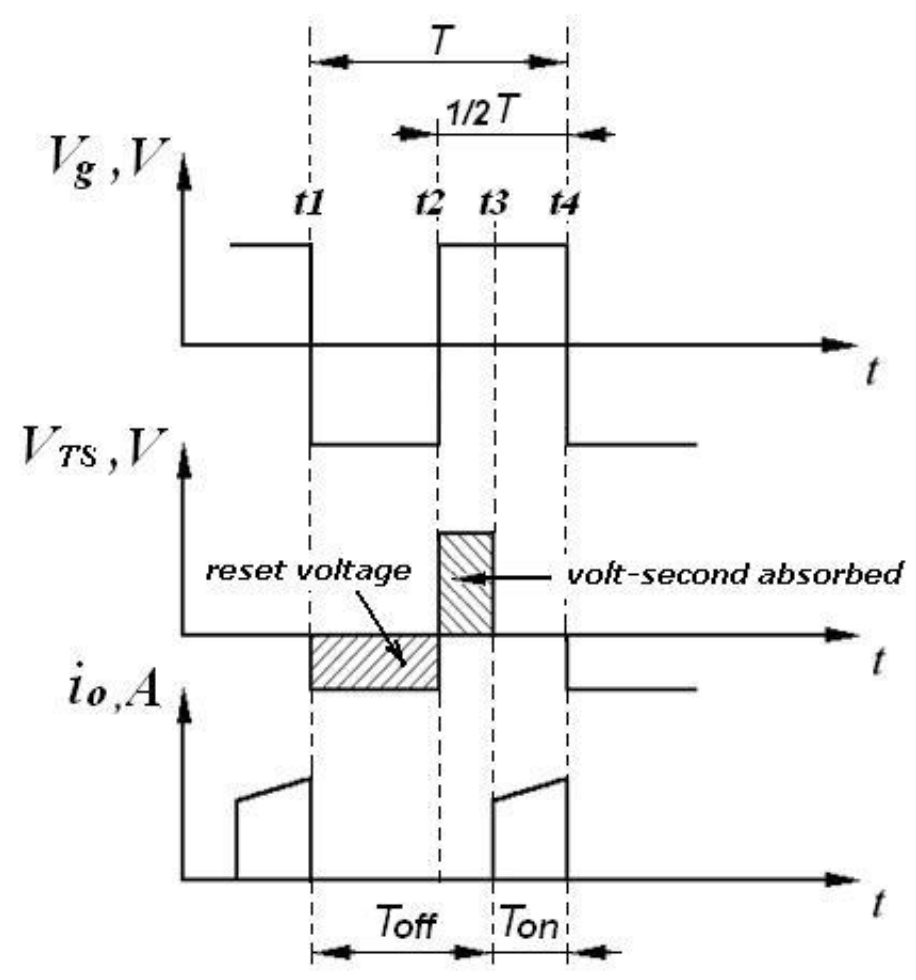

Fig. 2. Ideal MagAmp waveforms: $\mathrm{V}_{\mathrm{g}}$ - transformer secondary winding voltage, $\mathrm{V}_{\mathrm{MS}}-$ MagAmp switch voltage; $i_{o}$ - MagAmp switch output current [1]

The MagAmp core is unsaturated and due to high resistance there flows no current through its winding. When the input voltage changes its polarity to positive, MagAmp requires a certain volt-sec, which is the integral of voltage over time, to be applied to its terminals for the magnetic flux to build up in the core and reach the saturation level (interval $2-3$ in fig. $1 ; t_{2} \ldots t_{3}$ in fig. 2 ). When the magnetic inductance reaches the saturation level 
(slope 3-4 in fig. 1), the MagAmp resistance approaches zero, which allows the current to flow trough MagAmp's winding (interval $4-1$ in fig. $1 ; t_{3} \ldots t_{4}$ in fig. 2 ) $[1,13,14]$.

In fig. 3 there is presented a functional scheme of a dc voltage regulator based on high-frequency magnetic amplifiers, which contains an unregulated high-frequency transistor voltage inverter 1 , power transformer, push-pull centre-tapped rectifier, controlled MagAmps, output filter 2, load, control circuit 3, demagnetizing diodes $[1,15,16]$.

However, providing a high level of output current in such voltage regulator is followed by the increase of losses on the diodes of high-frequency rectifier. This leads to a significant decrease of efficiency.

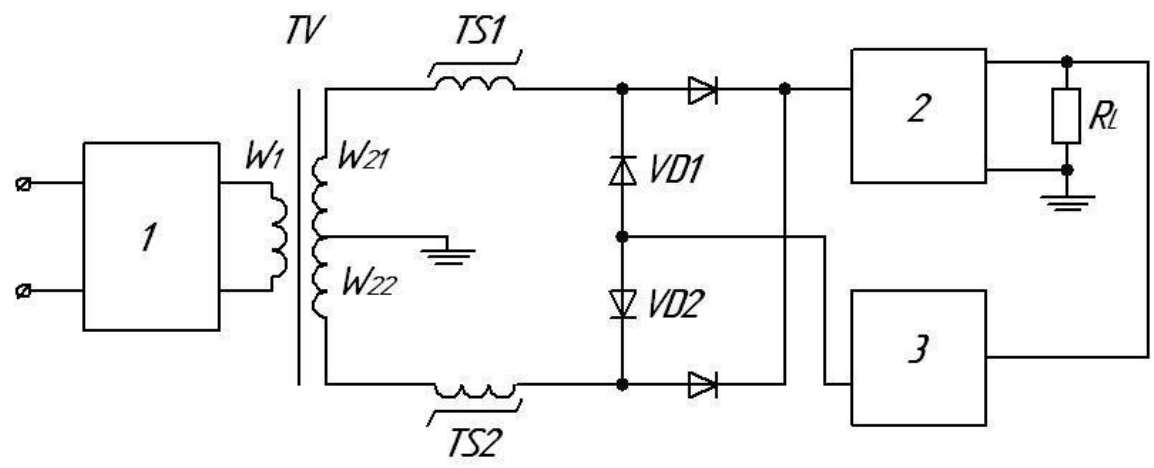

Fig. 3. Functional scheme of a dc voltage regulator based on high-frequency magnetic amplifiers [1]

\section{EXPERIMENTAL RESEARCH OF MAGAMP POWER CONVERTER WITH SYNGHRONOUS RECTIFIER}

In article $[1,17,18]$ the principle of operation of the proposed DC voltage stabilizer based on high-frequency magnetic amplifiers with synchronous rectification is described. This article also demonstrates the possibility of using a MOSFET instead of a high-frequency diode in the output LCD filter and substantiates its control of the MagAmp in a function of voltage, which in its turn is a function of the output current. The corresponding functional circuits and timing diagrams, which explain the principle of operation of the proposed topology, are explained.

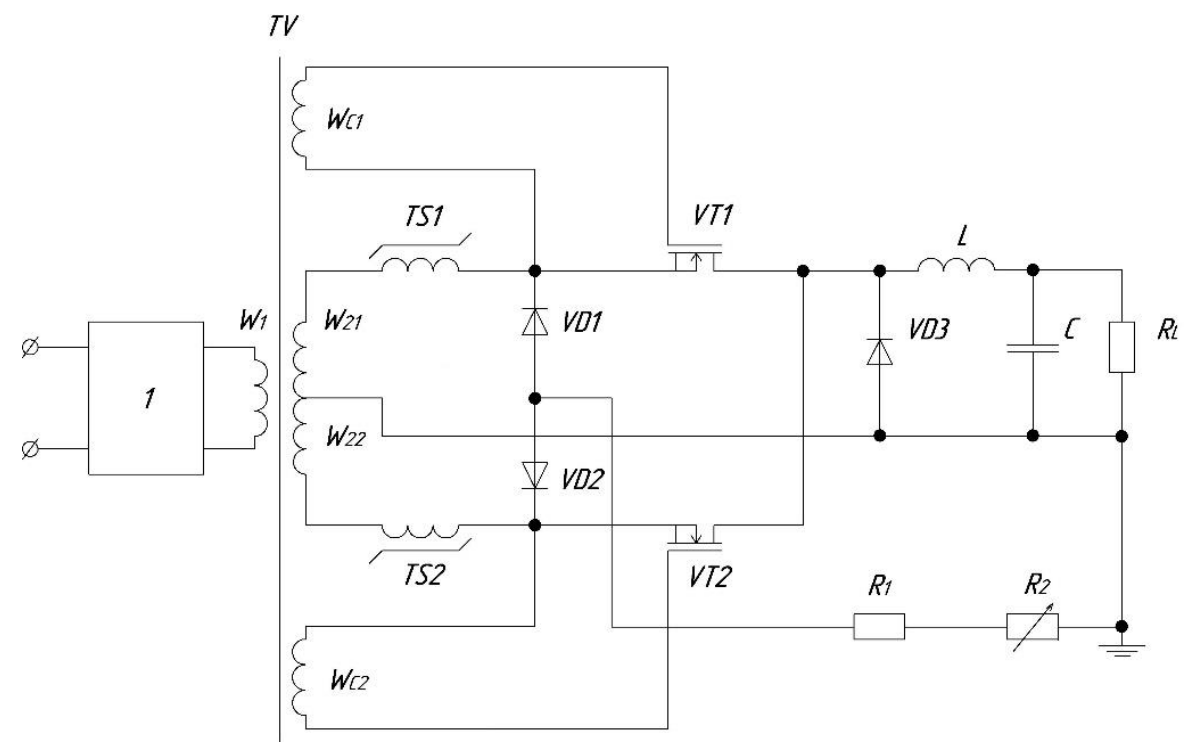

Fig. 4. The functional scheme of MagAmp power converter with synchronous rectifier without control circuit 
DIODE RECTIFIER

\begin{tabular}{|l|l|l|l|l|l|l|l|}
\hline $\begin{array}{l}\text { Input DC } \\
\text { voltage, V }\end{array}$ & 310 & 310 & 310 & 310 & 310 & 310 & 310 \\
\hline $\begin{array}{l}\text { Input DC } \\
\text { current, A }\end{array}$ & 0.025 & 0.2 & 0.39 & 0.58 & 0.77 & 0.95 & 1.06 \\
\hline $\begin{array}{l}\text { Output DC } \\
\text { voltage, V }\end{array}$ & 17.83 & 14.74 & 14.28 & 13.89 & 13.51 & 13.16 & 12.74 \\
\hline $\begin{array}{l}\text { Output DC } \\
\text { current, A }\end{array}$ & 0 & 4.1 & 7.9 & 11.9 & 16 & 20 & 22.6 \\
\hline Efficiency, \% & - & 95.22 & 93.31 & 91.93 & 90.55 & 89.37 & 87.62 \\
\hline
\end{tabular}

MOSFET SYNCHRONOUS RECTIFIER

\begin{tabular}{|l|l|l|l|l|l|l|l|}
\hline $\begin{array}{l}\text { Input DC } \\
\text { voltage, V }\end{array}$ & 310 & 310 & 310 & 310 & 310 & 310 & 310 \\
\hline $\begin{array}{l}\text { Input DC } \\
\text { current, A }\end{array}$ & 0.025 & 0.21 & 0.39 & 0.59 & 0.78 & 0.96 & 1.06 \\
\hline $\begin{array}{l}\text { Output DC } \\
\text { voltage, V }\end{array}$ & 17.83 & 14.74 & 14.62 & 14.26 & 13.98 & 13.53 & 13.23 \\
\hline $\begin{array}{l}\text { Output DC } \\
\text { current, A }\end{array}$ & 0 & 4.3 & 8 & 12.3 & 16.2 & 20.2 & 22.6 \\
\hline Efficiency, \% & - & 97.4 & 96.74 & 95.9 & 93.66 & 91.84 & 90.1 \\
\hline
\end{tabular}

This article explores power converter based on high-frequency magnetic amplifiers. As input highfrequency transistor inverter 1 used the converter on a half-bridge circuit on MOSFET IRF740 with a working frequency of $50 \mathrm{kHz}$. The IR2110 output driver is used to control the transistors in the control circuit. In all cases, the power converter with open loop was investigated (like Fig. 3 with no control circuit) at input DC voltage Uin $=310 \mathrm{~V}$.

At first, we investigated the converter using the MBR2080 diode in the output rectifier. The load characteristic of this converter has been obtained. The results are shown in Table I and Fig. 5.

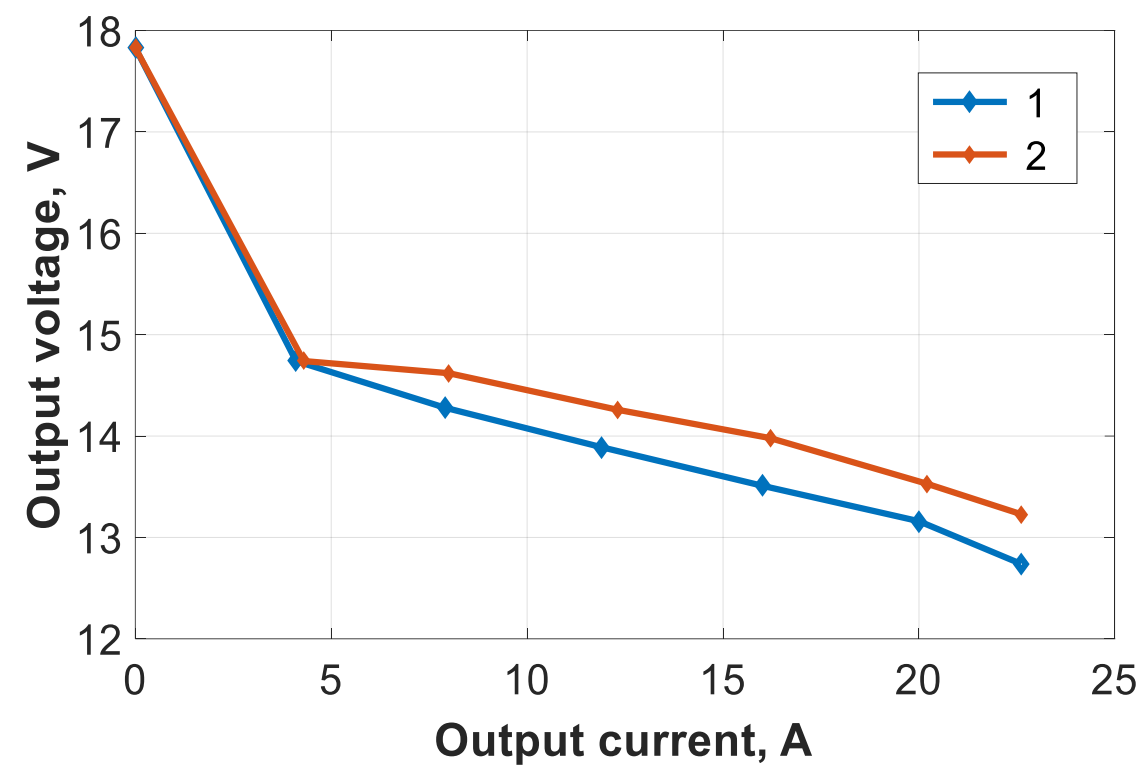

Fig. 5. Load characteristics of power converter with diode rectification (line 1) and with MOSFET synchronous rectification (line 2) 
Functional diagram of the power converter with the synchronous rectifier MOSFET IRL3705 with the channel resistance in 'on' state of $10 \mathrm{mOhm}$ is shown in Fig. 4. In order to control high-frequency MagAmps, two resistors were introduced into the remagnetization circuit - resistor R1 and potentiometer R2. The results of the external characteristics of this converter are shown in TABLE II and Fig. 5.

TABLE I and TABLE II summarize the results of the calculation of the efficiency for both cases. Charts 1 and 2 in Fig. 6 show the function of the efficiency dependence on the load current.

Waveforms of voltage of high-frequency power transformer TV and gate voltage of transistor VT1 at the load current $\mathrm{I}_{\mathrm{L}}=20$ A are shown on Fig.7. Waveforms of voltage on high-frequency power transformer TV secondary winding and output voltage ripple at the load current $\mathrm{I}_{\mathrm{L}}=20 \mathrm{~A}$ in power converter with open loop are shown on Fig. 8.

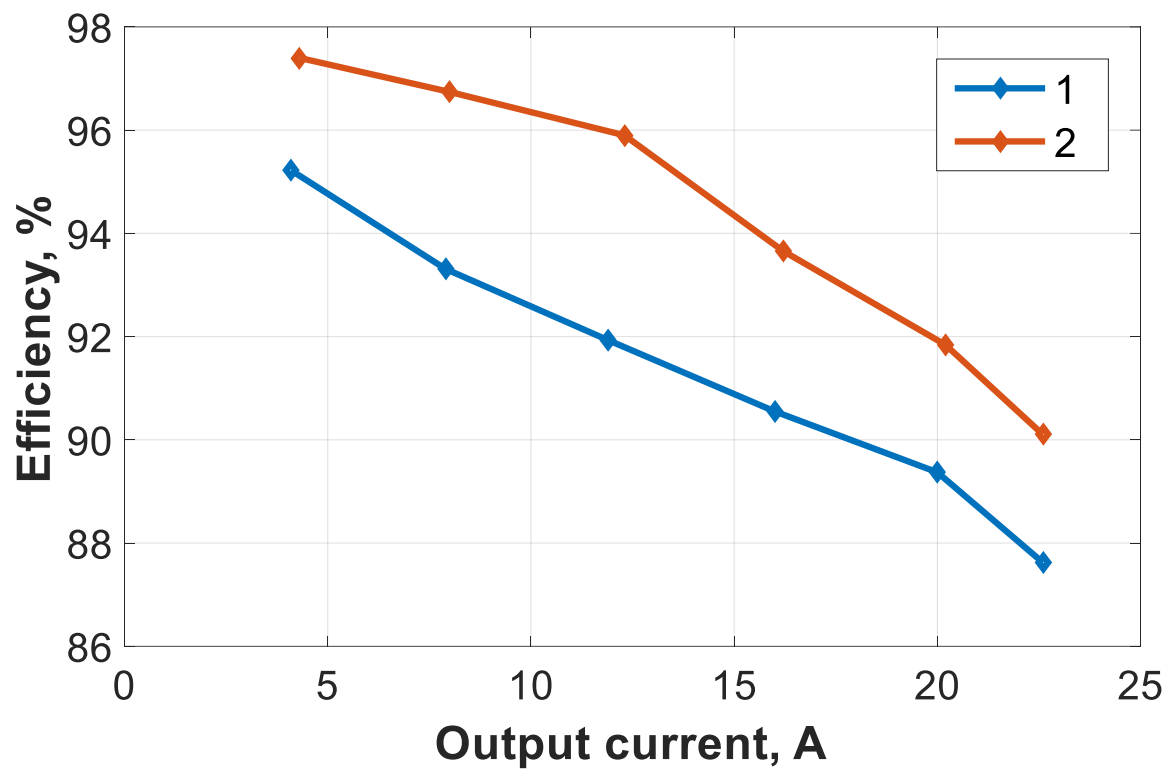

Fig. 6. Efficiency of power converter with diode rectification (line 1) and with MOSFET synchronous rectification (line 2)

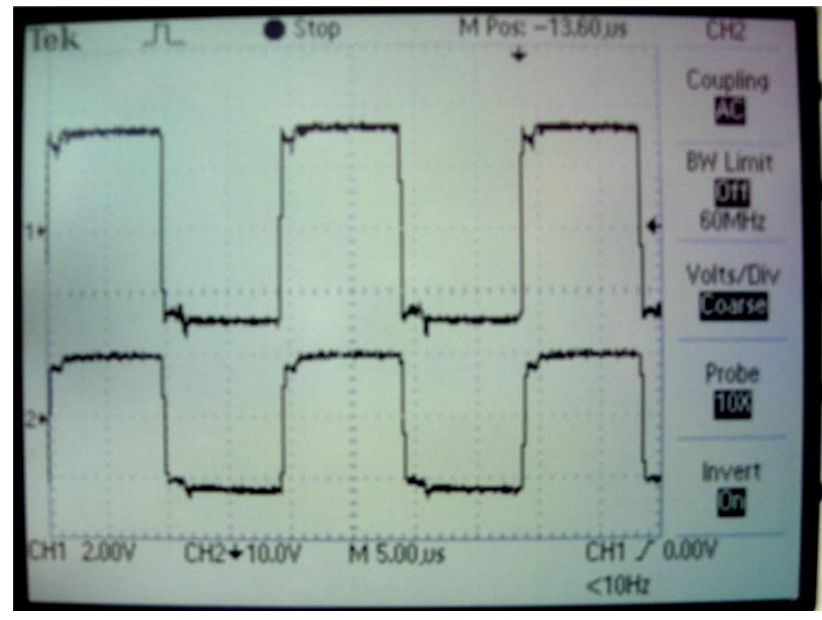

Fig. 7. Waveforms of voltage on secondary winding of high frequency power transformer TV and voltage on gate of transistor VT1 at the load current $\mathrm{I}_{\mathrm{L}}=20 \mathrm{~A}$. 


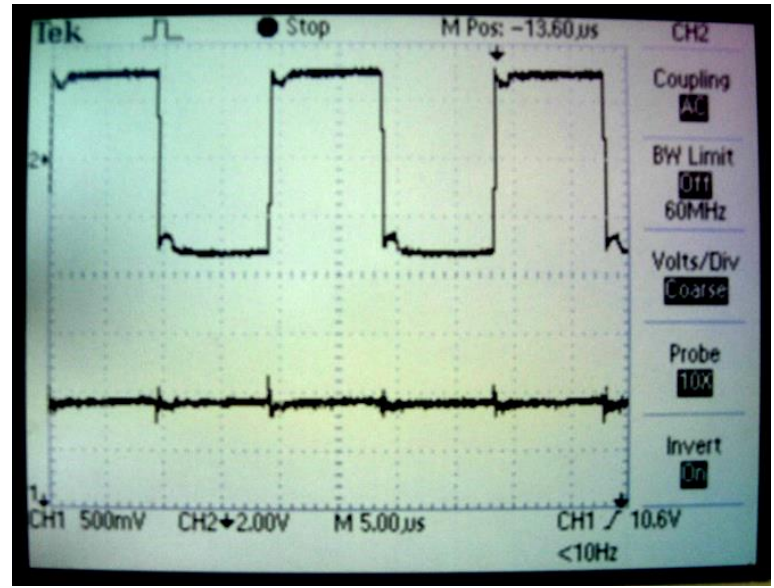

Fig. 8. Waveforms of voltage on secondary winding of high-frequency transformer TV and output voltage ripple at the load current $\mathrm{I}_{\mathrm{L}}=20 \mathrm{~A}$ in power converter without output voltage feedback.

Theoretical waveforms of MagAmp power converter with synchronous rectifier with MOSFET instead of output LCD filter diode [1,19] are shown on Fig. 9. The functional scheme of MagAmp power converter with synchronous rectifier without control circuit with MOSFET instead of output LCD filter diode is shown on Fig. 10.

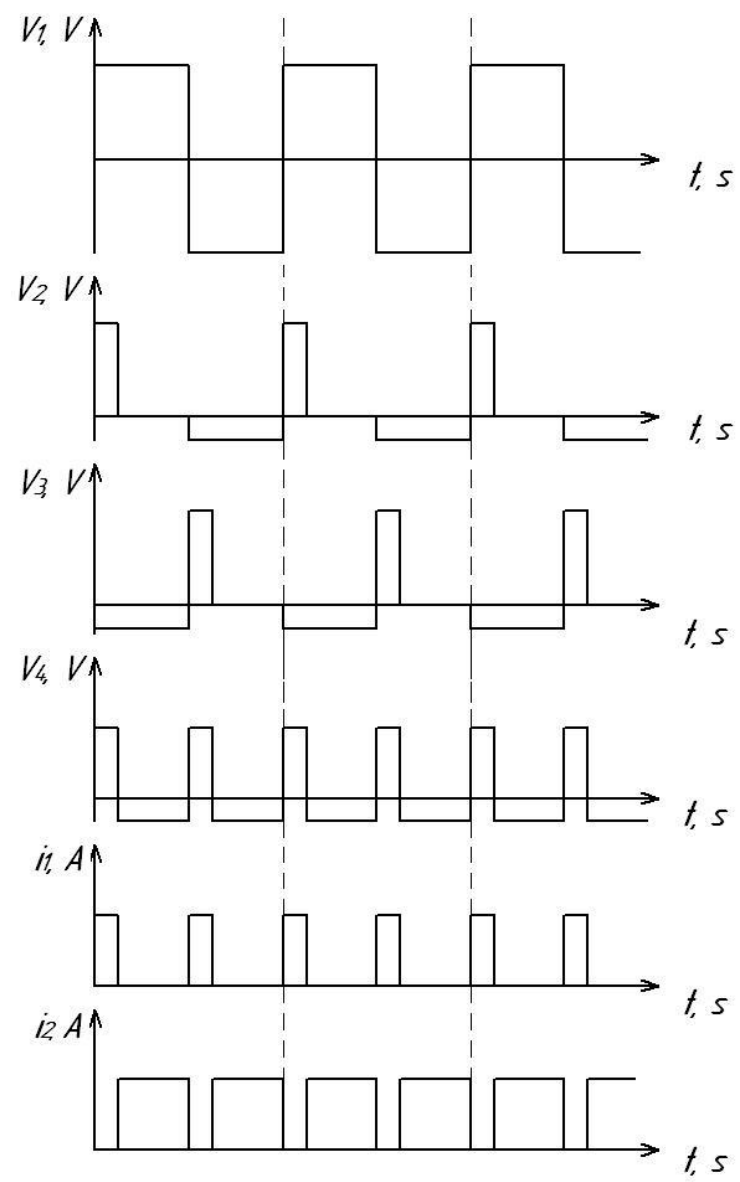

Fig. 9. Theoretical waveforms of MagAmp power converter with synchronous rectifier with MOSFET instead of output LCD filter diode [1]: $\mathrm{V}_{1}$ - voltage on secondary winding of high frequency power transformer TV; $\mathrm{V}_{2}$ $\mathrm{dB} / \mathrm{dt}$ (voltage) in high-frequency MagAmp core TS1; $\mathrm{V}_{3}-\mathrm{dB} / \mathrm{dt}$ (voltage) in high-frequency MagAmp core TS2; $\mathrm{V}_{4}$ - voltage on gate of transistor VT3; $\mathrm{i}_{1}$ - current through transistor VT3; $\mathrm{i}_{2}$ - load current. 


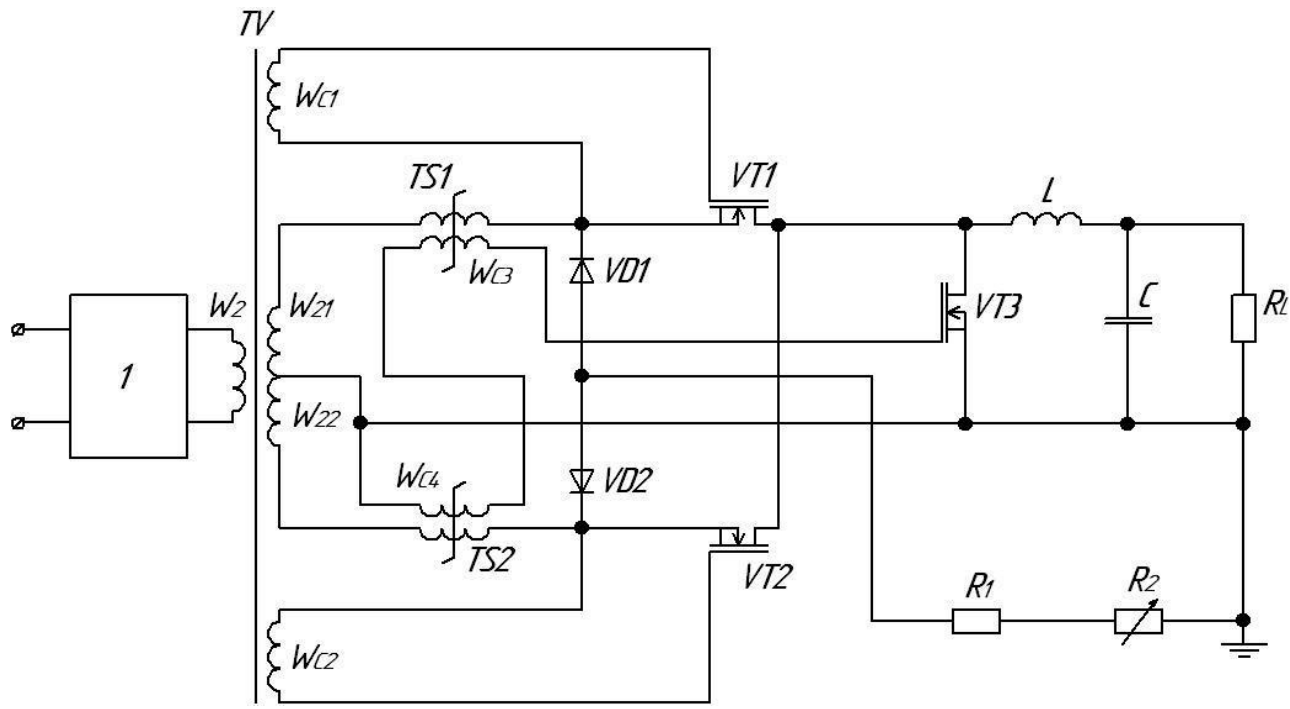

Fig. 10. The functional scheme of MagAmp power converter with synchronous rectifier without control circuit with MOSFET instead diode in output filter

With resistor R2 we change the remagnetization depth of MagAmps TS1 i TS2, which results in the load current change. Waveforms of $\mathrm{dB} / \mathrm{dt}$ in high-frequency MagAmp cores and winding voltage $\mathrm{W}_{\mathrm{C} 4}$ at transistor VT1 gate at the load current $\mathrm{I}_{\mathrm{L}}=12 \mathrm{~A}$ are shown on Fig. 11. Transistor VT1gate voltage at the load current $\mathrm{I}_{\mathrm{L}}=$ $12 \mathrm{~A}$ is shown on Fig. 12. Output filter current through MOSFET VT3 at the load current $\mathrm{I}_{\mathrm{L}}=12 \mathrm{~A}$ is shown on Fig. 13.

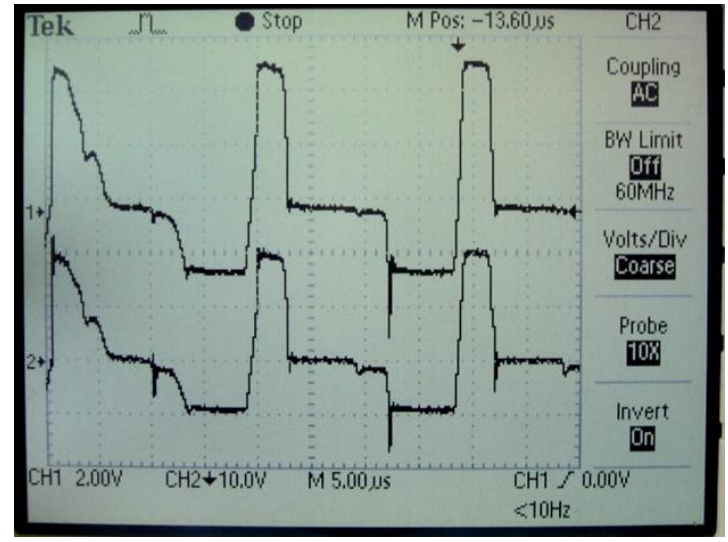

Fig. 11. Waveforms of $\mathrm{dB} / \mathrm{dt}$ in high-frequency MagAmp cores and winding voltage for gate of transistor VT1 at the load current $\mathrm{I}_{\mathrm{L}}=12 \mathrm{~A}$

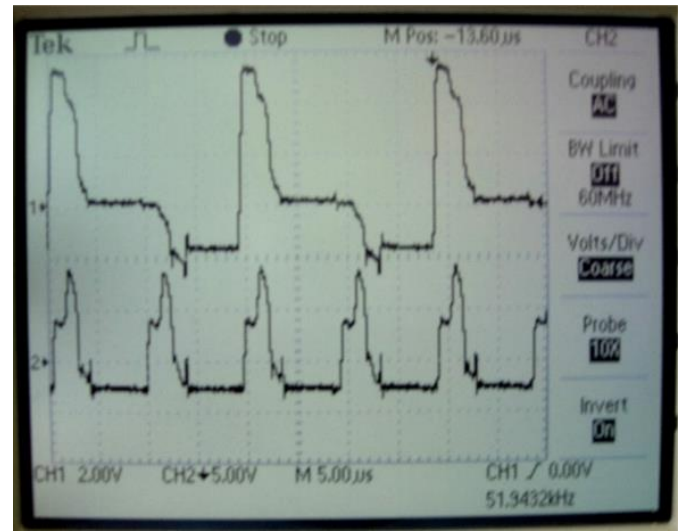

Fig. 12. Waveforms of $\mathrm{dB} / \mathrm{dt}$ in high-frequency MagAmp cores and gate voltage of transistor VT1 at the load current $\mathrm{I}_{\mathrm{L}}=12 \mathrm{~A}$ 


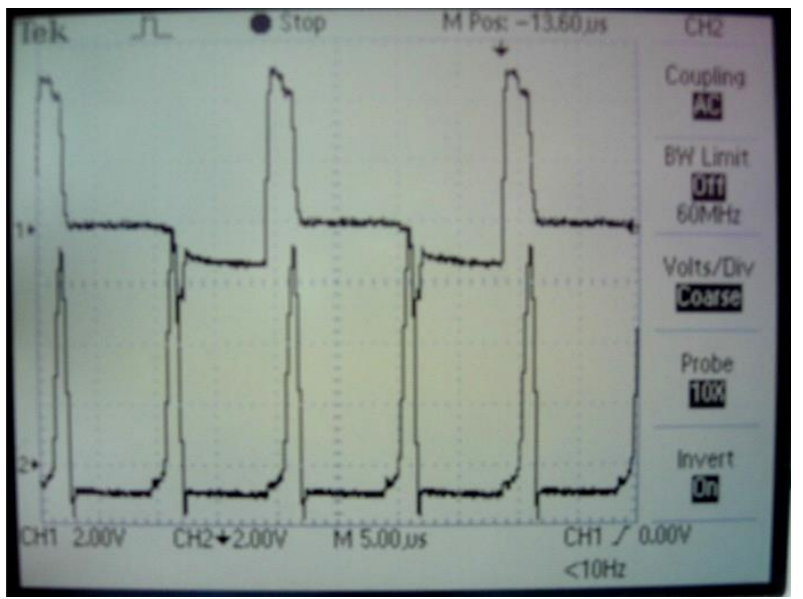

Fig. 13. Waveforms of $\mathrm{dB} / \mathrm{dt}$ in high-frequency MagAmp cores and of current through MOSFET VT3 in output filter at the load current $\mathrm{I}_{\mathrm{L}}=12 \mathrm{~A}$

\section{CONCLUSION}

Thus, the possibility of using MOSFET synchronous rectifiers in DC voltage gulators based on highfrequency magnetic amplifiers is experimentally confirmed in this article. It is the presence of high-frequency MagAmps switched on in series with the MOSFET that enables the current flow through push-pull rectifier circuit, thus allowing the use of a synchronous rectifier without the any drivers or control circuits.

High efficiency of the power converter based on high-frequency magnetic amplifiers with synchronous rectification is confirmed by analysis of its experimental loading characteristics in the open loop operation mode.

Some increase in efficiency is possible provided:

- optimization of the design of high-frequency power transformer, in particular the use of magnetic materials with the maximum possible saturation induction;

- development and optimization of operation modes of the high-frequency power transistor inverter, intended for joint work with DC regulators on the basis of high-frequency magnetic amplifiers. Such a converter should have high efficiency and prevent the magnetization of the high-frequency power transformer.

\section{REFERENCES}

1. V. Yaskiv, A. Yaskiv, O. Yurchenko, Synchronous Rectification in High-Frequency MagAmp Power Converters, in Proceedings of International conference Advanced Computer Information Technologies (ACIT), Ceske Budejovice, Czech Republic, 1-3 June 2018, pp. 128-131.

2. Fernandez, J. Sebastian, M. M. Hernando, P. Villegas, and D. G. Lamar, Using synchronous rectification for medium voltage applications, in PESC Record - IEEE Annual Power Electronics Specialists Conference, 2004, pp. 1487.

3. S. Mappu, Control driven synchronous rectifiers in phase shifted full bridge converters, Texas Instruments. Application Note. Power Supply Control Products, SLUA287, March 2003, 10 p.

4. Yang, J. Zhang, Effect and utilization of common source inductance in synchronous rectification., in Proceedings of Twentieth Annual IEEE Applied Power Electronics Conference and Exposition (APEC 2005), Austin, TX, USA, 6-10 March 2005, 5 p.

5. Fei, F. C. Lee, Q. Li, Digital implementation of adaptive synchronous rectifier (SR) driving scheme for LLC resonant converters, in Proceedings of Applied Power Electronics Conference and Exposition (APEC), IEEE 2016, pp. 322-328.

6. M. S. Amouzandeh, B. Mahdavikhah, A. Prodic, B. McDonald, Digital synchronous rectification controller for LLC resonant converters, in Proceedings of Applied Power Electronics Conference and Exposition (APEC), IEEE 2016, pp. 329-333.

7. Y. Gu, Z. Lu, Z. Qian, G. Huang, A novel driving scheme for synchronous rectifier suitable for modules in parallel, IEEE Transactions on Power Electronics, Vol. 20, No. 6, November 2005, pp. 1287-1293.

8. Yaskiv, V.Yaskiv, “DC voltage regulator,” Patent of Ukraine № 112231, issue date 10.08.2016.

9. MagAmp Cores and Materials, Technical Bulletin, BULLETIN SR-4, Magnetics Inc., available online at: http://www.mag-inc.com/design/technical-documents .

10. B. Mamano, "Magnetic amplifier control for simple, low-cost, secondary regulation," Unitrode corp. slup129, available on line at: http://www.ti.com/lit/ml/slup129/slup129.pdf .

11. K. Harada, T. Nabeshima, Applications of magnetic amplifiers to high-frequency dc-to-dc converters, Proc. IEEE, vol. 76, no. 4, April 1988, pp. 355-361. 
12. V. Yaskiv, A. Abramovitz, K. Smedley, A. Yaskiv, MagAmp regulated isolated ac-dc converter with high power factor, Special issue of journal COMMUNICATIONS - Scientific Letters of the University of Zilina, ISSN 1335-4205, No. 1A/2015, pp. 28-34.

13. Olexiy Azarov, Olexandr Chernyak, and etc. "High-speed counters in Fibonacci numerical system", Proc. SPIE 10445, Photonics Applications in Astronomy, Communications, Industry, and High Energy Physics Experiments 2017, 1044522 (7 August 2017)

14. Olexiy D. Azarov, Tetiana I. Troianovska, and etc. "Quality of content delivery in computer specialists training system", Proc. SPIE 10445, Photonics Applications in Astronomy, Communications, Industry, and High Energy Physics Experiments 2017.

15. Oleksyi D Azarov, Leonid V Krupelnitskyi, Paweł Komada. AD systems for processing of low frequency signals based on self calibrate ADC and DAC with weight redundancy// Przeglad Elektrotechniczny. - 2017. - R. 93 NR 5. - P. 125-128.

16. Osadchuk V.S., Osadchuk A.V. The Microelectronic Radiomeasuring Transducers of Magnetic Field with a Frequency Output // Electronics and Electrical Engineering. - Kaunas: Technologija, 2011. №4(110). - P.67-70.

17. Osadchuk V.S., Osadchuk A.V. The magneticreactive effect in transistors for construction transducers of magnetic field // Electronics and Electrical Engineering. - Kaunas: Technologija, 2011. -№3(109). P.119-122.

18. Osadchuk V.S., Osadchuk A.V. The microelectronic transducers of pressure with the frequency // Electronics and Electrical Engineering. - Kaunas: Technologija, 2012. -№5(121). -P.105-108.

19. Osadchuk V.S., Osadchuk A.V. Radiomeasuring Microelectronic Transducers of Physical Quantities // Proceedings of the 2015 International Siberian Conference on Control and Communications (SIBCON). 21-23 May 2015. Omsk.

Надійшла до редакції: 03.08.2019p.

ЯСБКІВ Володимир Іванович - к.т.н., доцент, декан факультету прикладних інформаційних технологій та електроінженерії Тернопільського національного технічного університету імені Івана Пулюя

Тел.:0677301149

E-mail: yaskiv@yahoo.com 